\title{
Diet study of Atlantic horse mackerel (Trachurus trachurus Linnaeus, I 758) (Carangiformes Carangidae) caught in Béni- Saf Bay, Western Mediterranean Sea (Algeria)
}

\author{
Khaled Rahmani I*, Fatiha Koudache', Farid Bennabi², Mohamed Walid Mohamedi ${ }^{3}$ \& Nasr Eddine Riad \\ Mouedden ${ }^{4}$ \\ ${ }^{1}$ University of Sidi Bel Abbès, Djillali Liabes, Laboratoire Ecodéveloppement des espaces, Sidi Bel Abbès 22000, Algeria \\ ${ }^{2}$ University Centre of Belhadj Bouchaib, Laboratory of Applied Chemistry, N95, Aïn Témouchent, Algeria \\ ${ }^{3}$ University of Sidi Bel Abbès, Djillali Liabes, Condensed Matter and sustainable development Laboratory (LMCDD) \\ ${ }^{4}$ University Centre of Belhadj Bouchaib, N95, Aïn Témouchent, Algeria \\ *Corresponding author, email: khaled46310@gmail.com
}

\begin{abstract}
This paper gives a description of the diet of Atlantic horse, Trachurus trachurus (Linnaeus, 1758) (Carangiformes Carangidae) living in the bay of Béni-Saf (North-Western Algeria) between November 2015 and October 2016 by analyzing the contents of the stomachs of 488 specimens divided in three classes according to the length of their body. We used several indices such as the coefficient vacancy $(\mathrm{V})$, the percentage of prey $(\mathrm{Cn})$ and the frequency of occurrence of prey (Fc). Of the total stomachs examined, 135 are empty which corresponds to a vacancy coefficient of 27.66. In total, 3912 preys were counted. They belong to ten major taxonomic groups: Copepoda, Euphausiacea, Amphipoda, Mysidacea, Cumaceae Cephalopods, Echinodermata, Molluscs, phytoplankton and Teleosts). The study of diet of T. trachurus shows that it has a broad food spectrum, and is a carnivorous and voracious species (benthpelagic). We found that the first class prefers Crustaceans, the second favors Euphausiacea, and the third prefers the predation of Teleosts. The diet varies with the size of specimens which is proportional to the size of the prey.
\end{abstract}

KEY WORDS

Diet, Atlantic horse mackerel; Trachurus trachurus; Béni-Saf Bay; food spectrum; prey.

Received 04.05.2020; accepted 20.09.2020; published online 30.12.2020

\section{INTRODUCTION}

Understanding the biology and ecology of fish in the wild inevitably involves studying their diet. The analysis of the contents of the stomach or of the entire digestive tract makes it possible to determine indirectly the composition of the diet and to assess the use of the food available. Processing of the collected data can be done by calorimetric (Rosecchi \& Nouaze, 1985), numerical, gravimetric, volumetric or occurrence methods (Hyslop, 1980). These different methods have given rise to food indices, which show the most important prey for the preda- tor's diet and allow inter-specific and intra-specific comparisons. Some authors group together the prey of a studies species, according to their index value, in order to separated the main prey from the others (Zander, 1982). It is in this context that our research falls, namely the study of the diet of the horse mackerel, Trachurus trachurus (Linnaeus, 1758) (Carangiformes Carangidae) caught in the west coast of Béni-Saf in western Algerian. We used food indices which tell us about the proportions of prey ingested and group them into "categories".

Horse mackerel has been the subject of several studies on reproduction (Korichi, 1988; Tahari, 
2011; Aydin \& Erdoğan, 2018; Gherram, 2019; Rahmani \& Koudach, 2020), growth (Karlou-Riga \& Sinis, 1997; Abaunza et al., 2003; Kerkich et al., 2013), and diet (Olaso-Toca et al., 1999; Cabral \& Murta, 2002; Jardas et al., 2004; Šantić et al., 2005; Bahar \& Tuncay, 2009; Bayhan et al., 2013; Shawket et al., 2015). However, for the Algerian coasts, no important study has been carried out.

This paper focuses on the diet of Atlantic horse, T. trachurus, living in the Béni-Saf Bay (North-West Algeria) with emphasis on vacuity coefficient, the Corrected frequency index of a prey (FC) and the Percentage in number of a prey $(\mathrm{Cn} \%)$ to complete gaps in life cycle of this Carangidae and better manage this resource in that part of the Algerien coast.

\section{MATERIAL AND METHODS}

The samples of hores mackerel (Trachurus trachurus) come from commercial catches landed in the port of Béni-Saf in the western Mediterranean Sea, between the Habibas islands to the east and the tip of Rachgoun to the west, between longitude $1^{\circ}$ 10 and $1^{\circ} 30$ West (Fig. 1). Sampling was carried out monthly between November 2015 and October 2016. The individuals come from trawls (bottom and beam trawls) carried out at a depth of 30 and $130 \mathrm{~m}$. For each individual we noted the height and the weight.

They have been divided into three size classes:

- Class 1: total length $\leq 12 \mathrm{~mm}$ Small.

- Class 2: $12 \mathrm{~cm}<$ total length $<20 \mathrm{~cm}$ Medium.

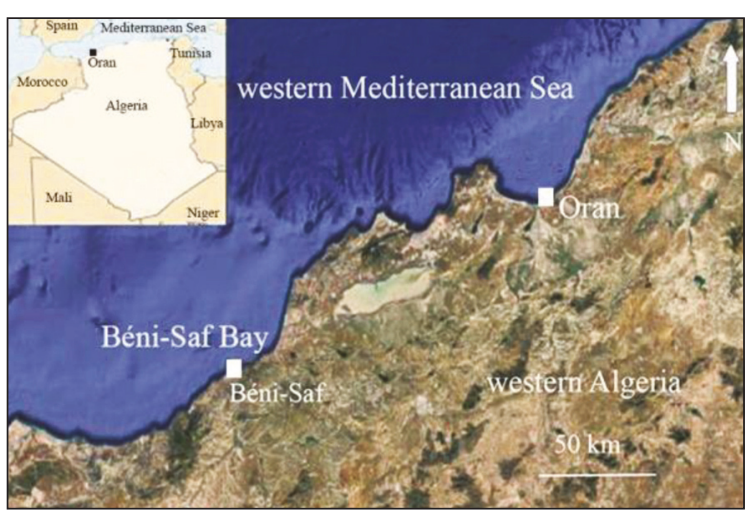

Figure 1. Geographical localization of the study area: Béni-Saf Bay, Algeria.
- Class 3: total length $\geq 20 \mathrm{~cm}$ Large.

The individuals are then dissected in order to recover the entire digestive tract immediately after capture, and then the stomach contents are stored in a formalin solution (10\%). The ingested preys are identified with a binocular magnifier up to the family level, then under the microscope to possibly continue until the species. The excessively altered remains were classified in the indeterminate group. We used several identification keys (Rioja \& Lo Bianco, 1928; Pasteur-Humbert, 1962; Bellon-Humbert, 1973; Kensley, 1978; Ruffo, 1982, 1989; Ledoyer, 1983; Sarda, 1984; Fischer et al., 1987a, b).

The stomach contents are grouped by month and by season, to obtain representative samples. These groups are: October, November and December in autumn, February-March in winter, April, May and June in spring and July, August and September in summer. To deepen the study of different diets and their variations, we used the mixed method (qualitative and quantitative), as well as different dietary indices.

\section{Sex ratio}

It is defined as being the proportion of the male or female individuals compared to the total number of individuals. It also gives an idea on the balance of the sexes within the population. The sex-ratio generally translates the rate of femininity or masculinity of the population:

$\mathrm{SR}=\mathrm{F} /(\mathrm{M}+\mathrm{F})^{*} 100($ Kartas \& Quignard, 1984)

$\mathrm{F}=$ number of females; $\mathrm{M}=$ number of males.

\section{Vacuity coefficient (V)}

It is the ratio (in percentage) of the number of empty stomachs to the total number of stomachs examined. This coefficient makes it possible to identify, over time, the periods of weak and intense trophic activities in fish.

\section{$\mathrm{V}=\mathrm{NEV} / \mathrm{NET}$}

NEV: number of empty stomachs.

NET: total number of stomachs. 


\section{The Corrected Frequency Index of a prey (FC)}

According to Gray et al. (1997), it is calculated as follows:

$\mathrm{FC}=F i / \sum F i * 100$ with $F i=n i P_{\mathrm{i}}$

$F i=$ the frequency index of a prey.

$n i=$ number of stomachs containing the prey $\mathrm{i}$.

$\mathrm{NP}=$ number of number of stomachs containing the prey $\mathrm{i}$.

\section{Percentage in number of prey (Cn)}

It is the ratio (in percentage) of the total number of individuals of a prey $p$ on the total number of the various prey ingested per batch of $\mathrm{n}$ fish. (Table 1 ).

$$
\begin{aligned}
& \mathrm{Cn}=100 * \mathrm{Pi} / \mathrm{P} \\
& \mathrm{Pi}=\text { total number of individuals of a prey. } \\
& \mathrm{P}=\text { the total number of various prey. }
\end{aligned}
$$

\section{RESULTS}

In total, 488 specimens of T. trachurus were collected (Fig. 2), 240 males (49.18\%), 208 females $(42.62 \%)$ and 40 unsexed (8.20\%).

The length frequency distribution of the entire population is shown in figure 2, male length range was 10.2 to $34.4 \mathrm{~cm}$, female length range was 9.1 to $35.1 \mathrm{~cm}$ while males weight varied between 11.38 and $301.27 \mathrm{~g}$ and females' weight varied between 5.09 and $343.41 \mathrm{~g}$.

\section{Sex Ratio}

From a 12-month sample represented by a workforce of 488 individuals, we obtained a total masculinity rate of $53.57 \%$ for a total femininity rate of $46.43 \%$ (Fig. 3). Overall, in our sample, there is a convergence between the two sexes ratio with a slight favor of males. In addition, the variations in sex ratio according to size is in favor of females whose total length is less than 16.5 .

In sizes between 16.5 and $35.5 \mathrm{~cm}$, males outnumbered females, except for size $34.5 \mathrm{~cm}$ and 35.5 $\mathrm{cm}$, where females outnumbered males. Monthly variations of sex-ratio (Fig. 3) reveal that females

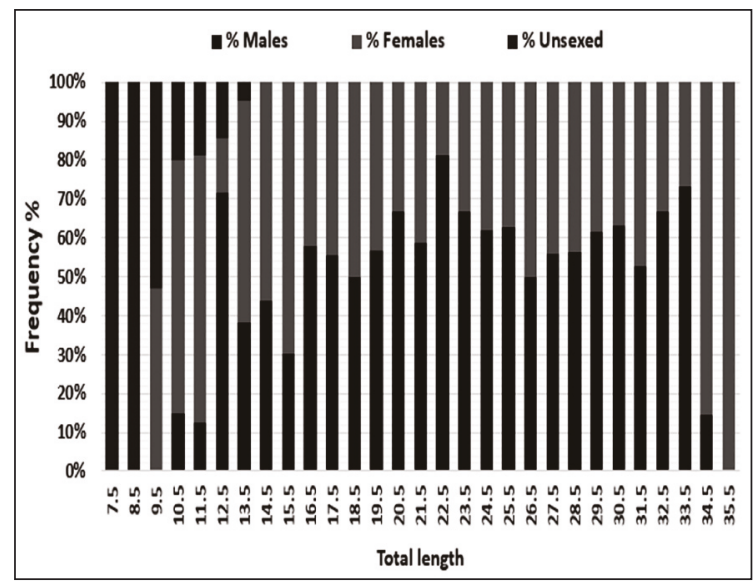

Figure 2. Trachurus trachurus length frequency distribution of males and females caught in Béni-Saf Bay.

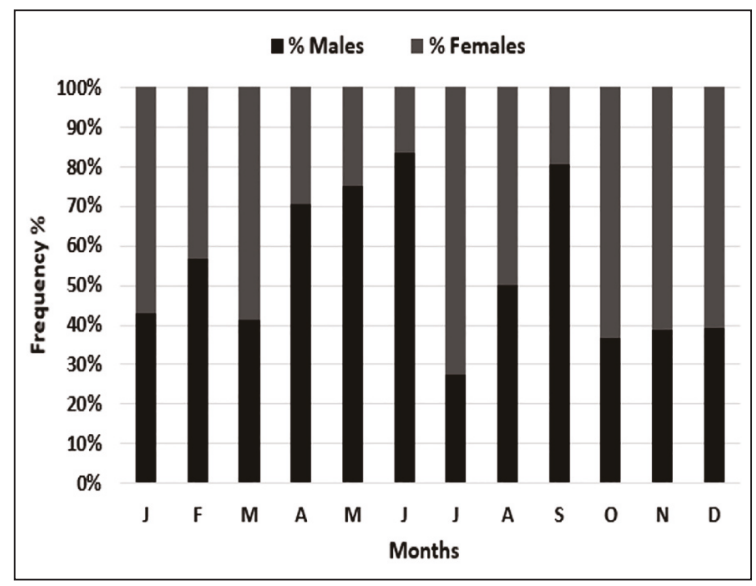

Figure 3. Monthly evolution of Sex ratio of Trachurus trachurus caught in Béni-Saf Bay.

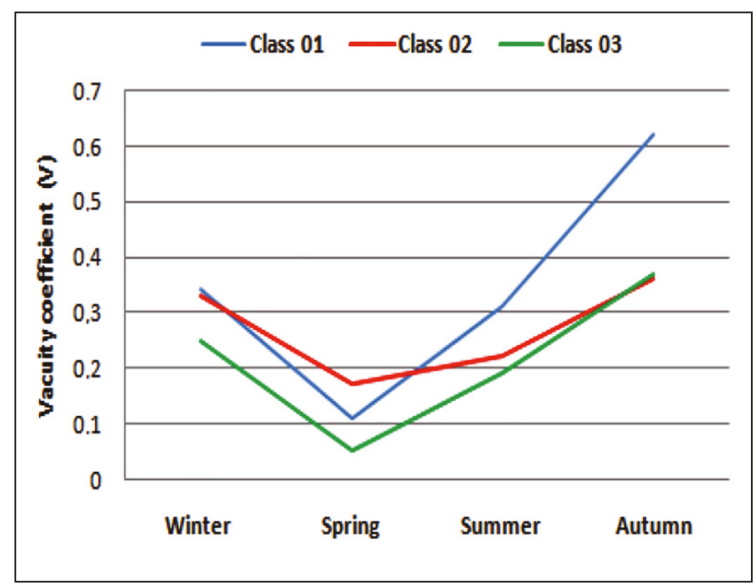

Figure 4. Seasonal variation of vacuity coefficient of Trachurus trachurus. 
dominate during the months of January, March, July, October, November and December. And males dominate during February, April, May, June, and September, with a numerical equality in August. Evolution of sex-ratio related to seasons (Fig. 5) showed that females dominate in the winter period while males dominate in the spring-summer-autumn period.

\section{Vacuity coefficient (V)}

The Vacuity coefficient shows seasonal fluctuations (Fig. 4). This coefficient displays the lowest values during the spring season, which is explained by the abundance of prey in the environment. While it marks the highest values in the autumn period, which indicates the scarcity of prey in the environ-

\begin{tabular}{|c|c|c|}
\hline $\mathrm{Cn} \%$ & Fc\% & Category of Prey \\
\hline \multirow{2}{*}{$\begin{array}{c}C n>50 \\
\text { Main prey }\end{array}$} & FC $>30$ : Preferential & Main Preferential \\
\hline & $\mathrm{FC}<30$ : Occasional & Main Occasional \\
\hline \multirow{2}{*}{$\begin{array}{c}10<\mathrm{Cn}<50 \\
\text { Secondary prey }\end{array}$} & $\mathrm{FC}>10:$ Frequent & Secondary Frequent \\
\hline & $\mathrm{FC}<10$ : Accessory & Secondary Aceassoire \\
\hline \multirow{2}{*}{$\begin{array}{c}1<\mathrm{Cn}<10 \\
\text { Complementary prey }\end{array}$} & $\mathrm{FC}>10: 1^{\text {st }}$ Order & Complementary $1^{\text {st }}$ Order \\
\hline & $\mathrm{FC}<10: 2^{\text {nd }}$ Order & Complementary $2^{\text {nd }}$ Order \\
\hline Cn<1: accidental prey & accidental prey & accidental \\
\hline
\end{tabular}

Table 1. Classification of prey according to $\mathrm{Cn}$ and $\mathrm{Fc}$ (Hureau. 1970).

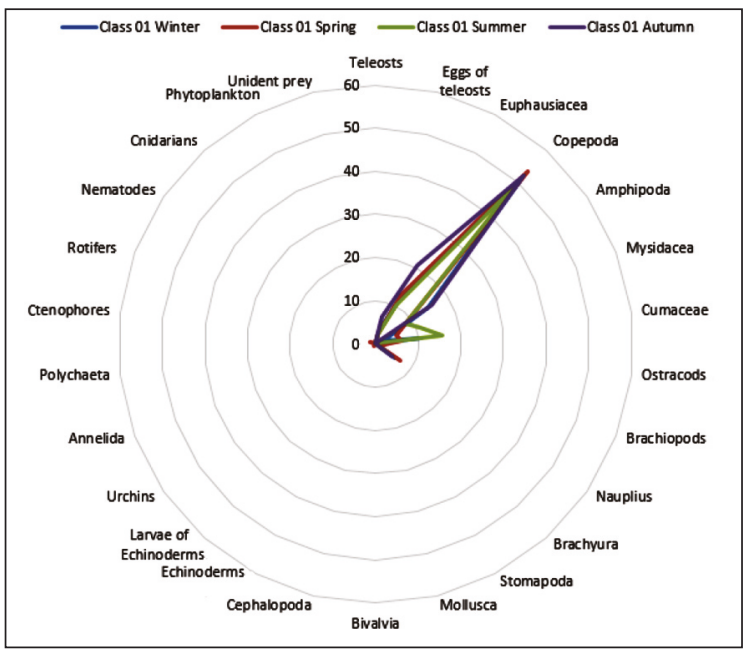

Figure 5. Seasonal composition of the diet of Trachurus trachurus (class 1) caught in Béni-Saf Bay. ment, which leads to feeding difficulties and cause the fish to eat less.

\section{Composition of the diet according to the season}

\section{Class 1}

The food spectrum included 8 preys in winter, 14 in spring, 7 in summer and 5 in autumn (Fig. 5).

In winter, Copepoda are the main prey. Amphipoda, Cumaceae and Euphausiacea are secondary prey. The Nauplius and eggs of Teleosts constitutes the complementary prey of 2 nd order. The rest are accidental prey. In spring, prey appears more diverse. The Copepods constitute the main prey, the Euphausiacea constitute the secondary prey. Amphipods, Cumaceae and Nauplius are complementary prey (1st order). The Mysidacea, squid and eggs of Teleosts are complementary prey (2nd order). The remains of Brachiopods, Echinoderms and Mollusc are accidentally preyed. In summer, the consumption is focused on Crustacea, but there is no main prey. The Euphausiacea and the Amphipods constitute the secondary accessory prey, the eggs of Teleosts and Nauplius are complementary prey (2nd order). There is no accidental prey. In Autumn, the foods of this fish is based on the Copepods which constitute the main prey. Euphausiacea and Amphipods take a more important place but remain secondary prey. Eggs of Teleosts are complementary prey. There is no lack of acidental prey.

\section{Class 2}

The food spectrum includes 12 preys in winter, 20 in spring, 11 in summer and 8 in autumn (Fig. $6)$.

In winter there is no main principal prey. Compared to the first class, Euphausiacea occupy a large place. The decrease in the consummation of Copepods was offset by an increase in that of Euphausiacea which then became the preferred prey of this size class, but it remains classified in the category of secondary prey. In addition, we note the emergence of a new prey, Small fish (Teleosts) and squid as secondary prey. Amphipods are complimentary prey (2nd order). We have also recorded the appearance of Stomapods, Bivalvia, and larvae of Echinoderm as accidental prey. 
In spring, the fish keep the same winter feeding behaviour with the appearance of new preys. The Ostracoda, the Rotifers and Bivalvia as complementary prey (2nd order). The rest (crabs, Molluscs, echinoderm, Polychaeta, Ktenophores, Cnidarians, phytoplancton) constitute accidental prey.

During summer and autumn the fish maintain the same eating behaviour with slight differences, such as a higher predation of squid in autumn. Molluscs and Cnidarians appear as both accidental and new prey in summer.

\section{Class 3}

The food spectrum included 13 preys in winter, 20 in spring, 10 in summer and 8 in autumn (Fig. 7).

In winter, consumption is focused on the Small fish (Teleosts) which constitute the main prey, while Euphausiacea are secondary accessory prey. Our results show a significant reduction in Crustaceans considered complementary prey after having been a staple food of the two previous classes. The diet has also seen the emergence of a new prey of bivalvia as a complementary prey of the 2 nd order, the rest of the food represents accidental prey.

In spring and summer, the diet is almost identical; it does not contain main prey. In both seasons, it prefers to feed on Small fish but remain classified as secondary prey, followed by predation of Mysi-

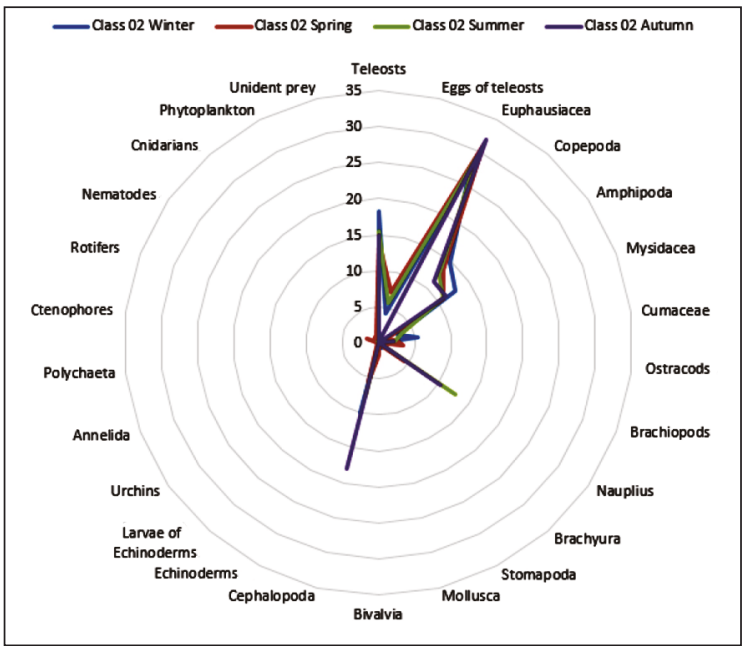

Figure 6. Seasonal composition of the diet of Trachurus trachurus (class 2) caught in Béni-Saf Bay. dacea and squid. The difference between the two seasons shows that the spring diet is more varied and results in the emergence of a new prey; the Stomapods as complementary prey (2nd order).

In autumn, the diet is entirely dominated by Small fish (Teleosts) (preferential primary prey), Euphausiacea and Amphipods are frequent secondary prey. The rest are accidental preys.

\section{DISCUSSION}

The diet study of $T$. trachurus has shown that this species has a wide food spectrum, and is an omnivorous and euryphagous fish. Its food is dominated by benthic (mainly Crustaceans) and pelagic (Copepods, Teleosts) prey, which is confirmed by (Jardas et al., 2004; Šantić et al., 2005; Bahar \& Tuncay, 2009; Cabral \& Murta, 2002; Bahar et al., 2013; Shawket et al., 2015; Koç \& Erdoğan, 2019).

The annual vacancy factor is $22.55 \%$ (110 empty stomachs), and we notice that it decreases with an increase in the size of individuals, as the highest values were recorded in young individuals and this is consistent with Shawket et al. (2015) and Koç \& Erdoğan (2019). The low vacancy factor during the spring and summer is due to the availability of prey. Also, the nutritional activity may be affected by physiological and ecological phenomena (such as reproduction and migration).

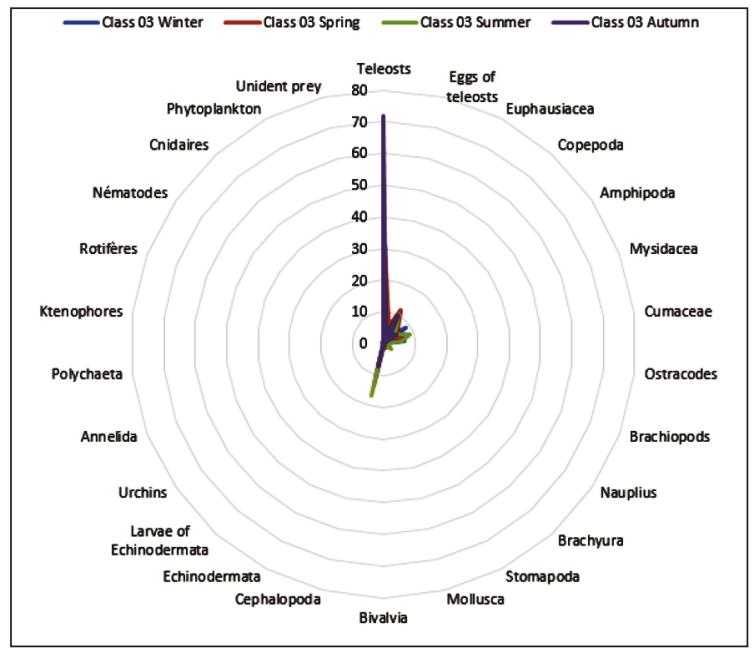

Figure 7. Seasonal composition of the diet of Trachurus trachurus (class 3) caught in Béni-Saf Bay. 
As the size class increases, the qualitative and quantitative composition of the food evolves, and the dietary diversity in the large T. trachurus suggests that they exploit a wide range of prey. The selection of the types of prey is in relation to the size of the predators (Chapman et al., 1988; Bayhan \& Tuncay, 2009; Shawket et al., 2015;), the size classes of T. trachurus exploit different types of prey, which would decrease the competition between small and large individuals, which is confirmed by Bănaru \& Harmelin-Vivien (2009).

The composition of the diet of this species is based on six major taxonomic groups (Euphausi- acea, Copepoda, Amphipoda, Mysidacea, Cumaceae and Teleosts), which is confirmed by several authors (Kompowski, 1976; Šantić et al., 2005; Bănaru, 2008; Bahar \& Tuncay, 2009; Bahar et al., 2013; Koç \& Erdoğan, 2019). The presence of supra-benthic taxa (Stomatopoda, Bivalvia, Echinoderma, cephalopoda, Brachyura) indicates, however, their expediency or aptitude to use sometimes more resources at the bottom. This fish shows a great plasticity of its diet and can feed whatever the environment, which is consistent with the study of Bănaru (2008).

The results that we obtained in this study show

\begin{tabular}{|c|c|c|c|c|c|c|c|c|c|c|c|c|}
\hline \multirow[b]{2}{*}{ Cn \% } & \multicolumn{4}{|c|}{ Class 01} & \multicolumn{4}{|c|}{ Class 02} & \multicolumn{4}{|c|}{ Class 03} \\
\hline & 咅 & 总 & 㟧 & 罡 & 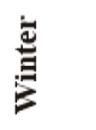 & 曾 & 离 & 罡 & 总 & 曾 & 离 & 罡 \\
\hline Teleosts & 0 & 0 & 0 & 0 & 18.29 & 13.94 & 15.56 & 14,84 & 53.06 & 41.61 & 40.46 & 71,7 \\
\hline Eggs of teleosts & 3.16 & 2.21 & 2.48 & 6.42 & 4.18 & 7.31 & 5.66 & 0.23 & 0.47 & 5.8 & 2.93 & 3.02 \\
\hline Euphausiacea & 12.69 & 13.11 & 10.34 & 20.67 & 27.26 & 31 & 29.05 & 31.86 & 11.77 & 11.69 & 10.32 & 9.94 \\
\hline Copepoda & 51.11 & 53.4 & 49.01 & 52.04 & 14.71 & 13.5 & 12.56 & 11.36 & 4.77 & 6.59 & 5.39 & 2.14 \\
\hline Amphipoda & 14.67 & 8.53 & 8.34 & 15.96 & 12.8 & 10.75 & 10.88 & 11.28 & 8.7 & 4.27 & 5.6 & 5.02 \\
\hline Mysidacea & 1.8 & 5.25 & 10.97 & 0 & 2,89 & 0.63 & 3.5 & 0 & 0.3 & 8.31 & 8.99 & 0 \\
\hline Cumaceae & 10.64 & 6.1 & 15.68 & 0 & 5,47 & 2.5 & 2.26 & 2.08 & 6.51 & 0.82 & 5.88 & 0 \\
\hline Ostracodes & 0 & 1.73 & 0 & 0 & 0 & 3.44 & 0 & 0 & 0 & 0,3 & 0 & 0 \\
\hline Brachiopods & 0 & 0.12 & 0 & 0 & 0 & 0 & 0 & 0 & 0 & 0 & 0 & 0 \\
\hline Nauplius & 5.54 & 6.89 & 2.94 & 4.91 & 3.15 & 4,38 & 12.77 & 10.36 & 1.22 & 2,23 & 2.77 & 0.26 \\
\hline Brachyura & 0 & 0 & 0 & 0 & 0.1 & 0.81 & 0 & 0 & 0.43 & 0.42 & 0 & 0.61 \\
\hline Stomapoda & 0 & 0 & 0 & 0 & 0.88 & 0 & 0 & 0 & 0 & 1.56 & 0 & 0 \\
\hline Mollusca & 0.11 & 0.03 & 0 & 0 & 0 & 0.22 & 0.1 & 0 & 0.06 & 0.72 & 0 & 0 \\
\hline Bivalvia & 0 & 0.09 & 0 & 0 & 0.1 & 1.66 & 0 & 0 & 1.1 & 0.96 & 0 & 0 \\
\hline Cephalopoda & 0 & 0 & 0 & 0 & 10,12 & 5,66 & 7,51 & 17.99 & 11.13 & 13.2 & 16.98 & 7.31 \\
\hline Echinodermata & 0 & 0 & 0 & 0 & 0 & 0,06 & 0 & 0 & 0 & 0 & 0 & 0 \\
\hline $\begin{array}{l}\text { Larvae of } \\
\text { Echinodermata }\end{array}$ & 0 & 0.54 & 0 & 0 & 0.05 & 0.28 & 0 & 0 & 0 & 0,18 & 0 & 0 \\
\hline Urchins & 0 & 0.06 & 0 & 0 & 0 & 0 & 0 & 0 & 0 & 0 & 0 & 0 \\
\hline Annelida & 0 & 0 & 0 & 0 & 0 & 0 & 0 & 0 & 0 & 0.18 & 0 & 0 \\
\hline Polychaeta & 0 & 0 & 0 & 0 & 0 & 0.28 & 0 & 0 & 0 & 0 & 0 & 0 \\
\hline Ktenophores & 0 & 0 & 0 & 0 & 0 & 0.13 & 0 & 0 & 0 & 0 & 0 & 0 \\
\hline Rotifères & 0 & 1.49 & 0 & 0 & 0 & 1.66 & 0 & 0 & 0 & 0.3 & 0 & 0 \\
\hline Nématodes & 0 & 0 & 0 & 0 & 0 & 0 & 0 & 0 & 0.3 & 0.66 & 0 & 0 \\
\hline Cnidaires & 0 & 0 & 0 & 0 & 0 & 0.03 & 0.15 & 0 & 0 & 0.06 & 0.05 & 0 \\
\hline Phytoplankton & 0 & 0 & 0 & 0 & 0 & 0.88 & 0 & 0 & 0 & 0.14 & 0 & 0 \\
\hline Unident prey & 0.28 & 0.45 & 0.24 & 0 & 0 & 0,88 & 0 & 0 & 0,18 & 0 & 0.63 & 0 \\
\hline
\end{tabular}

Table 2. Composition of the diet of Trachurus trachurus according to $\mathrm{Cn} \%$. 
that the main prey of the horse mackerel of the Bay of Béni-Saf are crustaceans for a size of fish lower than $20 \mathrm{~cm}$. Beyond this size (TL $20 \mathrm{~cm}$ ) Small fish (Teleosts) are the preferred prey.

\section{CONCLUSIONS}

Our study has shown that the horse mackerel $T$. trachurus of Béni-Saf bay (North-Western Mediterranean Sea) is a carnivorous species (benthopelagic), whose food spectrum consists mainly of Crustaceans (Copepods, Euphausiacea, Am- phipods, Mysidacea, Cumaceae), Cephalopods and vertebrae (Teleosts and Eggs of teleosts). In the first two size classes $(\mathrm{Lt}<20 \mathrm{~cm})$, Crustaceans constitute the most important group of prey, for class 3 (Lt> $20 \mathrm{~cm}$ ), Teleosts (anchovies, sardines) constitute the group most preferable prey. We conclude that the diet of this fish is very flexible as it changes prey in proportion to predation capacity and environmental conditions.

There is little seasonal variation in the diet, crustaceans were the dominant prey in all seasons for the first two size classes, while fishes were the dominant prey in class 3 (Table 3 ).

\begin{tabular}{|c|c|c|c|}
\hline & Class & Class & Class \\
\hline Teleosts & --- & Secondary Frequent & Main Preferential \\
\hline Eggs of teleosts & Complementary $1^{\text {st }}$ Order & Complementary $2^{\text {nd }}$ Order & Complementary $2^{\text {nd }}$ Order \\
\hline Euphausiacea & Secondary Frequent & Secondary Frequent & Secondary Frequent \\
\hline Copepoda & Main Preferential & Secondary Frequent & Complementary $2^{\text {nd }}$ Order \\
\hline Amphipods & Secondary Frequent & Secondary Frequent & Complementary $1^{\text {st }}$ Order \\
\hline Mysidacea & Complementary $2^{\text {nd }}$ Order & Complementary $2^{\text {nd }}$ Order & Complementary $2^{\text {nd }}$ Order \\
\hline Cumaceae & Complementary $1^{\text {st }}$ Order & Complementary $2^{\text {nd }}$ Order & Complementary $2^{\text {nd }}$ Order \\
\hline Ostracods & accidental & accidental & accidental \\
\hline Brachiopods & accidental & --- & --- \\
\hline Nauplius & Complementary $2^{\text {nd }}$ Order & Complementary $2^{\text {nd }}$ Order & Complementary $2^{\text {nd }}$ Order \\
\hline Brachyura & --- & accidental & accidental \\
\hline Stomapoda & --- & accidental & accidental \\
\hline Mollusca & accidental & accidental & accidental \\
\hline Bivalvia & accidental & accidental & accidental \\
\hline Cephalopoda & --- & Secondary Frequent & Secondary Frequent \\
\hline Echinoderms & --- & accidental & --- \\
\hline $\begin{array}{r}\text { larvae of } \\
\text { Echinoderms }\end{array}$ & accidental & accidental & accidental \\
\hline Urchins & accidental & --- & --- \\
\hline Annelida & --- & --- & accidental \\
\hline Polychaeta & --- & accidental & --- \\
\hline Ctenophores & --- & accidental & --- \\
\hline Rotiferes & accidental & accidental & accidental \\
\hline Nematods & --- & --- & accidental \\
\hline Cnidarians & --- & accidental & accidental \\
\hline Phytoplankton & --- & accidental & accidental \\
\hline Unident prey & accidental & accidental & accidental \\
\hline
\end{tabular}

Table 3. Categories of preys ingested by horse mackerel (Trachurus trachurus). 


\section{ACKNOWLEDGEMENTS}

This research did not receive any specific grant from public or commercial institutions. The authors are grateful to Dr. Nbati Abdelkader (University Centre of Belhadj Bouchaib, Algeria) for the editing and to Dr Benyoucef Fatima (University of Abou Bakr Belkaid Tlemcen, Algeria) for his technical support. The authors are grateful to coast guards of Béni-Saf for their precious help and also grateful to reviewers who improved the manuscript with their precious advices and directives.

\section{REFERENCES}

Abaunza P., Gordo L., Karlou-Riga C., Murta A., Eltink A.T.G.W., Santamaría M.G. \& Molloy J., 2003. Growth and reproduction of horse mackerel, Trachurus trachurus (Carangidae). Reviews in Fish Biology and Fisheries, 13: 27-61. https://doi.org/10.1023/A:10263345323 90

Aydin G.U. \& Erdoğan Z., 2018. Edremit Körfezi (Kuzey Ege Denizi, Türkiye)'nden avlanan Trachurus trachurus (L., 1758) un bazı üreme özellikleri. Balıkesir Üniversitesi Fen Bilimleri Enstitüsü Dergisi, 20, 164-176. https://doi.org/ 10.25092/baunfbed.412525

Bănaru D., 2008. Influence des apports du Danube sur les réseaux trophiques des poissons de la côte roumaine (mer Noire) (Doctoral dissertation, Aix-Marseille 2).

Bănaru D. \& Harmelin-Vivien M., 2009. Trophic links and riverine effects on food webs of pelagic fish of the north-western Black Sea. Marine and Freshwater Research, 60: 529-540. https://doi.org/10.1071/MF08005

Berg J., 1979. Discussion of methods of investigating the food of fishes, with reference to a preliminary study of the prey of Gobiusculus flavescens (Gobiidae). Marine Biology, 50: 263-273.

Bayhan B., Sever T.M. \& Kara A., 2013. Diet composition of the Mediterranean horse mackerel, Trachurus mediterraneus (Steindachner, 1868) (Osteichthyes: Carangidae), from the Aegean Sea. Belgian Journal of Zoology, 143: $15-22$.
Bahar Bayhan \& Tuncay Murat Sever (2009) Food and feeding habits of the Atlantic Horse Mackerel, Trachurus trachurus, from the Aegean Sea (Osteichthyes: Carangidae). Zoology in the Middle East, 46: 47-54, https://doi.org/10. 1080/09397140.2009.10638327

Bellon-Humbert C., 1973. Les mollusques marins testacés du Maroc. Premier supplément. Vol. 37 of Travaux de l'Institut Scientifique chérifien, $144 \mathrm{pp}$.

Cabral H.N. \& Murta A.G., 2002. The diet of blue whiting, hake, horse mackerel and mackerel off Portugal. Journal of Applied Ichthyology, 18: 14. https://doi.org/10.1046/j.1439-0426.2002. 00297.x

Chapman L.J., Mackay W.C. \& Wilkinson C.W., 1989. Feeding flexibility in northern pike (Esox lucius): fish versus invertebrate prey. Canadian Journal of Fisheries and Aquatic Sciences, 46: 666-669. https://doi.org/10.1139/f89-085

Fischer W., Bauchot M.L \& Schneider M., 1987a Fiches FAO d'identification des espèces pour les besoins de la pêche. (Revision 1). Méditerranée et mer Noire. Zone de pêche 37 . Volume I. Végëtaux et Invertébrés. Publication préparée par la FAO, résultant d'un accord entre la FAO et la Commission des Communautés européennes (Project GCP/INT/422/EEC) financée conjointe- ment par ces deux organisations. Rome, FAO, Vol. 1, 760 pp.

Fischer W., Bauchot M.L. \& Schneider M., 1987b. Fiches FAO. D'identification des espèces pour les besoins de la pêche. Méditerranée et mer Noire. Zone de pêche 37. Vol. II. Vertébrés FAO, Vol. 2, pp. 761-1530.

Gray A.E., Mulligan T.J. \& Hannah R.W., 1997. Food habits, occurrence, and population structure of the bat ray, Myliobatis californica, in Humboldt Bay, California. Environmental Biology of Fishes, 49: 227-238. https://doi.org/ 10.1023/A:1007379606233

Gherram M., Bensahla Talet A., Dalouche F. \& AbiAyad S.M.E.A., 2018. Study of reproductive aspects of Trachurus trachurus (Linnaeus, 1758) from western coast of Algeria, Indian Journal of Geo Marine Sciences, 47: 2469-2476.

Hureau J.C., 1970. Biologie comparée de quelques poissons antarctiques (Notothenüdae). Bulletin de l'Institut Océanographique de Monaco, 68: 1391: 1-250. 
Hyslop E.J., 1980. Stomach contents analysis - a review of methods and their application. Journal of Fish Biology, 17: 411-429.

Jardas I., Šantić M. \& Pallaoro A., 2004. Diet composition and feeding intensity of horse mackerel, Trachurus trachurus (Osteichthyes: Carangidae) in the eastern Adriatic. Marine Biology, 144: 1051-1056. https://doi.org/10.1007/s00227003-1281-7

Karlou-Riga C. \& Sinis A., 1997. Age and growth of horse mackerel, Trachurus trachurus (L.), in the Gulf of Saronikos (Greece). Fisheries research, 32: 157-171. https://doi.org/10.1016/ S0165-7836(97)00044-1

Kartas F. \& Quignard J.P., 1984. La fécondité des pois- sons téléostéens. Collection de Biologie des Milieux Marins, 5e Ed., Masson, 121 pp.

Kensley B., 1978. Guide to the Marine Isopods of South Africa. Trustees of the South African Museum, Cape Town, pp. 55-59.

Kerkich M., Aksissou M. \& Casal J.A.H., 2013. Age and growth of the horse mackerel Trachurus trachurus (Linnaeus, 1758) catches in the bay of M'diq (Mediterraneen coast of Morocco). Engineering Science and Technology, 3: 708-713.

Koç H.T. \& Erdoğan Z., 2019. Feeding Habits of the Mediterranean Horse Mackerel, Trachurus mediterraneus (Steindachner, 1868) in the Sea of Marmara (Bandırma Bay, Turkey). Natural and Engineering Sciences, 4: 182-193.

Kompowski A., 1976. A study of the food and feeding habits of Trachurus trachurus, T. trecae, T. picturatus and Caranx rhonchus in the region of Cape Blanc. Acta Ichthyologica et Piscatoria, 6: 35-57.

Korichi H.S., 1988. Contribution à l'étude biologique de deux espéces de saurels: Trachurus trachurus (Linne, 1758) et Trachurus mediterraneus (Steindachner, 1868) et de la dynamique de Trachurus trachurus en baie de Bou-Ismail (Alger). Doctoral dissertation, Ecole nationale supérieure des sciences de la mer et de l'aménagement du littoral.

Ledoyer M., 1982. Les Oedicerotidae (Crustacea Amphipoda) De La Mer Mediterranee. Memorie del Museo Civico di Storia Naturale di Verona, 9: 45-84.

Olaso-Toca L.I., Cendrero-Uceda O. \& AbaunzaMartínez P., 1999. The diet of the horse mack- erel, Trachurus trachurus (Linnaeus 1758), in the Cantabrian Sea (north of Spain).

Pasteur-Humbert C., 1962a. Les mollusques marins testacés du Maroc. Catalogue non critique. I Les Gastéropodes. L'Institut Scientifique chérifien Série Zoologie, 23: 1-245, pls. 1-42.

Rahmani K. \& Koudach F., 2020. Reproductive biology of horse mackerel, genus Trachurus Rafinesque, 1810 (Perciformes Carangidae), caught in Béni-Saf Bay, W-Mediterranean Sea (Algeria), Biodiversity Journal, 11: 389-398. https://doi.org/ 10.31396/Biodiv.Jour.2020.11. 2.389.398.

Rioja E. \& Lo Bianco S., 1931. Estudio de los poliquetos de la Península Ibérica. Memorias de la Academia de Ciencias Exactas, Fisicas y Naturales de Madrid. Serie Ciencias Naturale, 2: 1471.

Rosecchi E. \& Nouaze Y., 1985. Comparaison de cinq indices alimentaires utilisés dans l'analyse des contenus stomacaux. Revue des Travaux de l'Institut des Pêches maritimes, 49: 111-123.

Ruffo S., 1982. The Amphipoda of the Mediterranean. Part 1. Gammaridae (Acanthonotozomatidae to Gammaridae). Mémoire de l'Institut océanographique de Monaco, 13: 1364.

Ruffo S., 1989. The Amphipoda of the Mediterranean. Part. 2 (Haustoriidae to Lysianassidae). Mémoire de l'Institut océanographique de Monaco, 13: 365-576.

Šantić M., Jardas I. \& Pallaoro A., 2005. Feeding habits of horse mackerel, Trachurus trachurus (Linneaus, 1758), from the central Adriatic Sea. Journal of Applied Ichthyology, 21: 125-130. https://doi.org/10.1111/j.1439-0426.2004. 00603.x

Shawket N., Youssir S., El Halouani H., Elmadhi Y., El Kharrim K., \& Belghyti D., 2015. Description des habitudes alimentaires du chinchard Trachurus trachurus de l'atlantique Nord Marocain. European Scientific Journal, 11: 294 304.

Sardá R., 1984. Estudio sobre los Poliquetos de las zonas mediolitoral e infralitoral en la región del Estrecho de Gibraltar (Doctoral dissertation, Tesis doctoral. Univ. Barcelona).

Tahari F.Z., 2011. Contribution a l'étude de la biologie de la reproduction d'un petit pélagique le saurel Trachurus trachurus: Spermatogenèse, 
Condition, RGS, RHS. Thèse de Magister. Université d'Oran, Algeria, $69 \mathrm{pp}$.

Temming A. \& Herrmann J.P., 2001. Gastric evacuation in horse mackerel. I. The effects of meal size, temperature and predator weight. Journal of Fish Biology, 58: 1230-1245. https://doi. org/10.1111/j.1095-8649.2001.tb02282.x

Zander C.D., 1982. Feeding ecology of littoral Gobiid and Blennioid fishes of the Banyuls area (Mediterranean Sea) I. Main food and trophic dimension of niche and ecotope. Vie Milieu, 32: $1-10$. 